\title{
Clinical study of madhunash yoga with reference of bhaishajya ratnavali for diabetes mellitus
}

\author{
Volume 7 Issue 5 - 2017
}

\author{
Arpit Kumar Ranawat \\ Aradhya Ayurvedic Hospital \& Panchkarma research Centre, \\ India
}

\section{Clinical paper}

i. Owner and chief Ayurveda consultant of Aradhya Ayurvedic hospital and Panchkarma research centre, mandsaur 458001, India

ii. Owner and chief Ayurveda consultant of Aradhya Ayurvedic hospital and Panchkarma research centre, Pratapgarh, India

iii. Senior Ayurveda consultant at Garlico herbal International, Asaba, Delta state, Nigeria

\section{Place of study}

i. Aradhya Ayurvedic hospital \& Panchkarma research Centre, Mandsaur, India, Tel: +91-7422-404821, +91-95847-37163.

ii. Aradhya Ayurvedic hospital \& Panchkarma research Centre, Pratapgarh, India, Tel: +91-8989 774821.

\section{Purpose}

Diabetes is famous as a silent killer of the body. In this era it has been became a big and dangerous problem in the world. It brings other chronic and dangerous problem with it step by step. Generally people think that diabetes is incurable. Patient doesn't want to discover the region of starting and becoming incurable of this disease. Diabetes also increases the habits of life style which increase the incurability of this. This is basic logic to cure diabetes permanently.

The aim and objective of the study is to evaluate the effects of oral ayurvedia preparations to cure this problem permanently. This study shows how patient can forget this disease and live healthy life without any medicine.

\section{Method}

Firstly make a proper schedule which is generally following by the patient before the Ayurveda treatment and then prepare a list which is supporting to make stable this disease in the body like sleeping habits in day time, addictions like alcohol, nicotine, food habits like irregular lunch and dinner timings, lake of exercise and many more.

For this 200 patients of age more than 35years clinically diagnosed of Diabetes then divided into 2 groups, Group A \& Group B. each group contains 100 patients. Group A is treated with maintained life style such as walking, timely lunch and dinner, controlled sleep etc. Group B is treated only by medicine of Ayurveda. A group (Group C) is making of 25 patients of 8year to 35years.

All three groups treated by anti diabetes formulation (saptparni, gudmar, neem, maithika, karela etc all mixed as powder form reference of bhaishajya ratnavali). Group A and group C treated with maintained life style such as walking, food habits etc. after few months and after monitoring the fasting and post prandial blood sugar level, patients are selected to reduce the dose of medicine. This oral ayurveda medicine continued for 30months and Group A and Group $\mathrm{C}$ continued their life style for 6months more.

\section{Duration of the Study}

Starting date is 08 October 2013.

Completing date is 08 October 2016.

Treatment given for 30 months and monitor for 6 month without medicine. Total duration is of 36 months.

\section{Results}

After completing the above treatments with maintained dose of medicine and lifestyle $80 \%$ patients of group A showed their normal blood sugar level after 36 months without oral medicine, $60 \%$ patients of group B showed more than $80 \%$ relief and group C patients showed $90 \%$ normal blood sugar level without oral ayurveda medicine.

\section{Conclusion}

According to Ayurveda, dincharya (daily life style) with oral Ayurveda treatment can cure the disease. After stop the oral medicine patient must follow the life style.

\section{Acknowledgments}

None.

\section{Conflicts of interest}

ASuthor declares there are no conflicts of interest.

\section{Funding}

None. 